\title{
Probability Investigation of Thermal Runaway in Nickel- Cadmium Batteries with Pocket Electrodes
}

\author{
Nataliya N. Yazvinskaya ${ }^{1}$, Nikolay E. Galushkin ${ }^{1, *}$, Dmitriy N. Galushkin ${ }^{1}$, Inna A. Galushkina ${ }^{2}$ \\ ${ }^{1}$ Don State Technical University, Laboratory of electrochemical and hydrogen energy, 147 \\ Shevchenko Street, Town of Shakhty, Rostov Region, Russia, 346500. \\ ${ }^{2}$ Southern Federal University, Novoshakhtisk branch, 2 Oktiabria Street, Town of Novoshakhtinsk, \\ Rostov Region, Russia, 346900. \\ *E-mail: galushkinne@mail.ru
}

doi: $10.20964 / 2016.07 .81$

Received: 19 April 2016 / Accepted: 15 May 2016 / Published: 4 June 2016

In this study, there is shown that in nickel-cadmium batteries with pocket electrodes and a long operating life, a lot of hydrogen is contained just like in batteries with sintered electrodes. But a probability of the thermal runaway in the nickel-cadmium batteries with the pocket electrodes is much less than the same in the batteries with the sintered electrodes. This result can be of a great practical importance for new types development of the alkaline batteries with a good thermal runaway resistance.

Keywords: thermal runaway, battery, nickel-cadmium

\section{FULL TEXT}

(C) 2016 The Authors. Published by ESG (www.electrochemsci.org). This article is an open access article distributed under the terms and conditions of the Creative Commons Attribution license (http://creativecommons.org/licenses/by/4.0/). 